\title{
SOSIALISASI PENERAPAN PROTOKOL KESEHATAN PADA MASA PANDEMI COVID-19 DI DESA MAGUWOHARJO DAN SOSIALISASI DAMPAK PENGGUNAAN KANTONG PLASTIK SEKALI PAKAI DI DESA SUMBEREJO, SLEMAN, JAWA TENGAH
}

Implementation Socialization of Health Protocols during the Covid-19 Pandemic in Maguwoharjo Village and Socialization of the Impact of Using Single-use Plastic Bags in Sumberejo Village, Sleman, Central Java

Stephanie Astrid Ayu ${ }^{1)}$, Vinda Bivianti ${ }^{2)}$

Program Studi Manajemen, Fakultas Ekonomi, Universitas Katolik Darma Cendika Email: astrid.ayu@ukdc.ac.id

\begin{abstract}
ABSTRAK
Desa Maguwoharjo dan Desa Sumberejo merupakan daerah pemukiman di Provinsi Jawa Tengah yang masuk dalam kategori padat penduduk. Kondisi mayoritas penduduk di daerah tersebut cukup terpenuhi dalam segi ekonomi. Kondisi pandemi saat ini mempengaruhi kebiasaan dan rutinitas keseharian warga di lokasi pelaksanaan pengabdian masyarakat. Mayoritas warga Desa Maguwoharjo belum menyadari secara maksimal pentingnya menjaga dan menerapkan protokol kesehatan (meliputi 3M, menggunakan masker, mencuci tangan dengan sabun, dan menjaga jarak) sebagai salah satu upaya warga untuk membantu program pemerintah dalam menekan laju penyebaran virus Covid-19. Kondisi demografi mayoritas warga Desa Sumberejo, merupakan kelompok masyarakat yang belum sepenuhnya memahami dampak negatif dari menumpuknya limbah plastik sekali pakai yang sering digunakan oleh para Ibu rumah tangga dan warga lainnya dalam kehidupan sehari-hari. Berdasarkan dari permasalahan yang diuraikan di atas, maka program kerja pengabdian masyarakat ini berfokus pada pelaksanaan edukasi bagi warga Desa Maguwoharjo tentang pentingnya menerapkan protokol Kesehatan dalam hidup sehari-hari dan memberikan edukasi kepada masyarakat di Desa Sumberejo tentang dampak negatif penggunaan kantong plastik sekali pakai yang menyebabkan limbah plastik semakin banyak.
\end{abstract}

Kata Kunci: protokol kesehatan, implementasi, edukasi, dampak kantong plastik, kebersihan

\section{ABSTRACT}

Maguwoharjo village and Sumberejo village are residential areas in Central Java province that fall into the densely populated category. The condition of most of the population in the area is quite fulfilled in terms of economy. Current pandemic conditions affect the daily habits and routines of citizens at the location of community service. The majority of Maguwoharjo villagers have not realized the maximum importance of maintaining and implementing health protokols (including 3M, using masks, washing hands with soap, and maintaining distance) as one of the efforts of residents to help government programs in suppressing the rate of spread of the Covid-19virus. While the condition of the majority of Sumberejo villagers, is a community group that has do not understand the negative impact of the accumulation of singleuse plastik waste that is often used by housewives and other residents in everyday life. Based 
on the problems outlined above, this community service work program focuses on the implementation of education for Maguwoharjo villagers about the importance of implementing health protokols in everyday life and providing education to the community in Sumberejo Village about the negative impact of single-use plastic bag use that causes more and more plastik waste.

\section{Keywords: health protokol, implementation, education, plastik bag impact, hygien}

\section{PENDAHULUAN}

Program kerja pengabdian ini disusun sebagai bentuk media pembelajaran bagi para mahasiswa dalam bentuk pengabdian kepada masyarakat sekitar lokasi tempat tinggal atau kota domisili masing-masing. Dikarenakan pandemi yang masih belum dinyatakan selesai oleh pemerintah Indonesia, maka pelaksanaan kegiatan pengabdian masyarakat dilaksanakan seminimal mungkin melibatkan banyak orang, namun tetap mempertahankan kualitas capaian dan pembelajaran yang diperoleh mahasiswa selama program kerja pengabdian masyarakat ini dilaksanakan.

Pelaksanaan program kerja Pengabdian Masyarakat ini dilaksanakan di dua lokasi yang berbeda, mengingat jarak dan situasi anggota tim pelaksana kegiatan yang saat ini memang berada di kota asal masing-masing selama pandemi.

Proses pembelajaran dimulai sejak mahasiswa ditugaskan untuk menyusun program pengabdian yang sangat sesuai dengan daerah lokasi tempat tinggal, sehingga manfaat dari program kerja pengabdian masyarakat ini bisa dirasakan oleh seluruh warga.

\section{Permasalahan Mitra}

Melalui hasil wawancara dan survey lokasi yang telah dilaksanakan kelompok 21 dengan Ketua RT/04 RW/09 Desa Maguwoharjo serta beberapa perwakilan warga diperoleh informasi bahwa pada masa pandemi ini yang menjadi fokus dan memerlukan perhatian adalah terdapat banyak warga yang tidak tertib dan tidak mematuhi protokol 3M (Memakai Masker, Mencuci Tangan, dan Menjaga Jarak). Beberapa narasumber menyatakan bahwa beberapa warga ditemukan melewati atau memasuki kawasan RT 04 RW 09 Desa Maguwoharjo tidak menggunakan masker, dan itu sangat meresahkan bagi beberapa warga yang melihatnya.

Berdasarkan hasil survei lokasi dan wawancara yang telah dilakukan di RT 04/ RW/04 Desa Sumberjo salah satu permasalahan yang dihadapi adalah kebiasaan para warga dalam menggunakan kantong plastik sekali pakai untuk membawa barang belanjaan, makanan, minuman, dan lain-lain. Kantong plastik bekas pakai itu tidak dikelola dengan baik, melainkan hanya dibuang begitu saja. Beberapa selokan tercemari dengan sampah kantong plastik bekas pakai yang digunakan warga.

\section{SOLUSI DAN TARGET LUARAN}

\section{Solusi Permasalahan}

Dari permasalahan mitra yang ada, maka program kerja Kelompok 21 Pengabdian masyarakat adalah sebagai berikut:

1. Melakukan penyuluhan pencegahan Covid-19 dengan cara memasang spanduk Kawasan Wajib Masker di dua titik lokasi permukiman warga desa.

2. Membagikan masker serta sabun cuci tangan ke beberapa rumah warga yang kurang mampu. 
3. Memberikan edukasi dan sosialisasi tentang dampak kantong plastik serta membagikan tas reusable sebagai pengganti kantong plastik.

Tujuan dalam program kerja tersebut adalah:

1. agar warga sekitar lebih mengerti dan peduli terhadap penyebaran Covid-19 dan memahami bahaya dan dampak yang akan terjadi apabila warga tidak mematuhi protokol 3M tersebut.

2. Berkontribusi menjaga kebersihan lingkungan dengan tidak menggunakan tas plastik sekali pakai. Pengurangan penggunaan kantong plastik sekali pakai belum banyak dilakukan di lingkungan warga sekitar, maka dari itu diperlukan adanya sosialisasi.

3. menambah pengetahuan serta meningkatkan kesadaran masyarakat tentang dampak penggunaan kantong plastik secara terus menerus dan memberikan solusi untuk mengurangi dampak yang akan terjadi.

4. Selain itu, kegiatan pengabdian masyarakat ini juga bertujuan untuk menjaga kelestarian lingkungan serta mendukung salah satu poin Sustaianable Development Goals (SDGs) 2030 yaitu konsumsi dan produksi yang bertanggungjawab (tujuan 12).

\section{Luaran dan Target Capaian}

Melalui analisis situasi yang dilakukan Kelompok 21 dan berdasarkan hasil koordinasi serta persetujuan warga lokasi pelaksanaan program pengabdian masyarakat, maka berikut solusi yang disusun dalam rangka mengatasi permasalahan yang ada di lokasi:

1. Memasang spanduk (Banner) "Area Wajib Masker" pada dua titik lokasi yang ada di RT 04 RW 09 Desa Maguwoharjo, untuk mengingatkan kembali pada masyarakat tentang pentingnya memakai masker dimasa pandemi COVID-19.

2. Membagikan masker kain yang bisa dicuci ulang, pertimbangan lainnya adalah masyarakat sekitar lebih nyaman menggunakan masker kain daripada masker Kesehatan karena bahan kain yang lebih halus dan tidak panas di kulit. Pembagian masker ini bertujuan agar warga yang masih belum menyadari manfaat menggunakan masker, dapat mulai menggunakan masker.

3. Membagikan sabun cuci tangan. Pembagian sabun cuci tangan ini bertujuan agar orang-orang selalu dapat mencuci atau membersihkan tangan setelah melakukan kegiatan.

4. Memberikan sosialisasi dan edukasi kepada warga sekitar tentang dampak penggunaan kantong plastik sekali pakai. Sosialisasi ini bertujuan untuk menambah pengetahuan serta meningkatkan kesadaran masyarakat tentang dampak penggunaan kantong plastik secara terus menerus dan memberikan solusi untuk mengurangi dampak yang akan terjadi.

5. Membagikan dan menempel poster untuk mengingatkan kembali pada warga sekitar tentang dampak penggunaan sampah plastik, serta membagikan tas reusable sebagai pengganti kantong plastik sekali pakai.

\section{METODE PELAKSANAAN}

\section{KEGIATAN}

Tahap awal dalam pelaksanaan Program Pengabdian Masyarakat Kelompok 21 di RT 04-RW IX Desa Maguwoharjo dan RT 04-RW IV Desa Sumberjo adalah wawancara dan survei lokasi yang dilakukan oleh mahasiswa yang berdomisili di lokasi tersebut. Kegiatan ini dilakukan untuk mendapatkan informasi permasalahan apa dihadapi oleh warga. Berdasarkan hasil wawancara saat pendataan diperoleh informasi bahwa banyak warga yang 
melintas atau melewati RT 04-RW IX Desa Maguwoharjo tidak menggunakan masker atau tidak mematuhi Protokol 3M (memakai masker, mencuci tangan, dan menjaga jarak). Hal ini menjadi penyebab keresahan masyarakat dan warga sekitar karena situasi pandemi yang belum berakhir. Permasalahan selanjutnya berdasarkan hasil wawancara serta survei lokasi yang dilaksanakan dengan warga RT 04 - RW IV Desa Sumberjo tentang bahaya penggunaan kantong plastik secara berlebihan beresiko menimbulkan pencemaran lingkungan.

$$
\text { Program Kerja Pengabdian }
$$

Masyarakat Kelompok 21 dilaksanakan terhitung mulai pada bulan Februari 2021 dan berakhir pada bulan Mei 2021. Lokasi yang menjadi tujuan pelaksanaan program kerja pengabdian masyarakat adalah RT 04 RW 09 Desa Maguwoharjo, Sleman, Daerah Istimewa Yogyakarta dan RT 04/ RW/04 Desa Sumberjo, Rembang, Jawa Tengah Program kerja pengabdian masyarakat Kelompok 21 ini bertujuan untuk meningkatkan pemahaman dan kesadaran masyarakat RT 04-RW IX Desa Maguwoharjo akan pentingnya penerapan hidup bersih dan sehat dengan sering mencuci tangan menggunakan air mengalir dan sabun setelah beraktivitas di luar rumah, pentingnya memakai masker dengan baik dan benar. Program kerja Pengabdian Masyarakat Kelompok 21 selanjutnya dimaksudkan untuk memberikan edukasi kepada warga RT 04-RW IV Desa Sumberjo tentang dampak penggunaan kantong plastik nonreusable beserta dengan cara mengendalikannya, serta pembagian tas kain sebagai alternatif pengganti kantong plastik nonreusable.

Program Kerja Pengabdian Masyarakat Kelompok 21 dimulai dengan memasang spanduk "Area Wajib Masker" di dua titik lokasi yang sering dilewati oleh warga atau pendatang RT 04 RW IX Desa Maguwoharjo. Selain itu dibagikan juga masker kain yang bisa dicuci ulang dan sabun cuci tangan agar warga sekitar dapat menjaga kebersihan dan tetap menaati protokol kesehatan (3M). Program kerja berikutnya adalah sosialisasi dengan tema "Diet Kantong Plastik" di salah satu kios sayur yang sering dikunjungi warga RT 04RW IV Desa Sumberjo dan melakukan sosialisasi singkat secara door-to-door ke rumah warga, serta membagikan tas kain sebagai alternatif pengganti kantong plastik nonreusable.

Sasaran dari pelaksanaan pendataan pembagian masker kain dan sabun cuci tangan adalah warga masyarakat RT 04-RW IX Desa Maguwoharjo, Kecamatan Depok, Kabupaten Sleman yang terdiri 30 KK dan 2 titik lokasi untuk pemasangan spanduk yang sering dilewati oleh warga. Sasaran dari program kerja sosialisasi dan pemberian solusi dampak penggunaan kantong plastik adalah warga RT 04-RW IV Desa Sumberjo yang berjenis kelamin wanita dengan usia dewasa (ibu-ibu) yang sering berbelanja menggunakan kantong plastik sekali pakai. Sasaran spesifiknya adalah ibu-ibu dan beberapa warga yang sering berbelanja di salah satu kios sayur yang ada di lokasi.

Tahapan akhir dari kegiatan pengabdian masyarakat ini diantaranya melakukan evaluasi mengenai program kerja pengabdian masyarakat yang telah dilaksanakan dan penyusunan laporan akhir sebagai bentuk pertanggungjawaban pelaksanaan program kerja pengabdian masyarakat.

\section{HASIL DAN PEMBAHASAN}

Adapun pelaksanaan setiap kegiatan yang dilakukan secara terperinci yaitu:

a. Diskusi penentuan tema pelaksanaan kegiatan Pengabdian Masyarakat.

Hasil dari diskusi tersebut menghasilkan keputusan tempat pelaksanaan pengabdian masyarakat dengan dua tema yaitu kesehatan dan kebersihan berada di dua lokasi, yaitu RT 04 RW 09 Desa Maguwoharjo, Kecamatan Depok, Kabupaten Sleman, DIY dan RT 04 RW 
04 Desa Sumberjo, Kecamatan Rembang, Kabupaten Rembang, Jawa Tengah.

b. Survei lokasi dan pertemuan dengan Ketua RT 04 RW 09 Desa Maguwoharjo Kecamatan Depok, Kabupaten Sleman, DIY dan Ketua RT 04 RW 04 Desa Sumberjo Rembang.

c. Analisa sosial di RT 04 RW 04 Desa Sumberjo Rembang dan RT 04 RW 09 Desa Maguwoharjo Kecamatan Depok, Kabupaten Sleman, DIY. Pelaksanaan Analisa social dilakukan dengan mengamati keadaan sekitar wilayah ini dari segi lingkungan, kebersihan serta kebiasaan masyarakat. Dari tahap ini diperoleh kesimpulan mengenai permasalahan yang terjadi di RT 04 RW 04 Desa Sumberjo Rembang.dan RT 04 RW 09 Desa Maguwoharjo Kecamatan Depok, Kabupaten Sleman, DIY. Kemudian Kelompok 21 menyusun program kerja sebagai solusi untuk mengatasi yang ada.

d. Melakukan pendataan dengan Ketua RT dan wawancara dengan warga setempat.

e. melakukan pendataan langsung dengan Bapak Ketua RT 04 serta melakukan wawancara dengan beberapa warga mengenai tanggapan warga tentang Covid-19 di RT 04 RW 09 Desa Maguwoharjo. Kelompok 21 Pengabdian Masyarakat juga menggali informasi masalah yang dihadapi warga setempat dalam situasi Pandemi. Berdasarkan hasil wawancara, banyak warga yang melintas atau melewati RT 04 RW 09 tidak menggunakan masker atau tidak mematuhi protokol 3M (Memakai Masker, Mencuci Tangan, dan Menjaga Jarak).

f. Permohonan izin kepada pemilik kios sayur tempat dilaksanakan program sosialisasi yang sering dikunjungi oleh warga setempat. Berdasarkan hasil survei yang telah dilakukan, tempat ini menjadi lokasi yang terbaik untuk melaksanakan sosialisasi karena banyak warga (ibu-ibu) yang berbelanja di tempat ini. g. Pelaksanaan program pembagian masker dan juga sabun cuci tangan kepada warga yang memang membutuhkan termasuk yang belum sadar akan pentingnya protokol 3M, serta pemasangan spanduk. Selain mempersiapkan masker, sabun cuci tangan disiapkan juga spanduk himbauan bagi warga "Area Wajib Masker" yang akan dipasang di titik lokasi keluar masuknya warga sekitar.

h. Pelaksanaan Sosialisasi dilaksanakan dengan jumlah warga yang hadir saat itu kurang lebih 17 orang dan mendengarkan sosialisasi secara bergantian. Sosialisasi dilakukan dengan membagikan brosur yang berisi informasi tentang dampak penggunaan kantong plastik untuk memudahkan warga dalam mengikuti jalannya kegiatan sosialisasi. Selain itu, Kelompok 21 membagikan tas reusable sebagai bentuk solusi dari permasalahan yang terjadi.

Melalui kegiatan program sosialisasi yang dilakukan tentang dampak penggunaan kantong plastik bagi lingkungan kepada warga (ibu-ibu) dan pemberian tas reusable dan pembagian masker kain, sabun cuci tangan dan pemasangan spanduk "Area Wajib Masker" sebagai solusinya, maka diharapkan memberikan beberapa perubahan dan manfaat bagi masyarakat lokasi pelaksanaan program kerja pengabdian masyarakat tersebut di antaranya:

a. Masyarakat mendapat pengetahuan akan pentingnya memakai masker dan mencuci tangan dimasa pandemi saat ini untuk mencegahan dan memutus rantai penyebaran Covid-19.

b. Meningkatnya kesadaran masyarakat akan menaati protokol kesehatan 3M (Memakai Masker, Mencuci Tangan, dan Menjaga Jarak)

c. Warga mendapat pengetahuan tentang dampak yang ditimbulkan oleh penggunaan kantong plastik yang 
berlebihan sehingga menjadi lebih waspada dengan bahaya kantong plastik.

d. Meningkatnya kesadaran warga untuk mengurangi penggunaan kantong plastik dengan beralih ke tas belanja reusable yang lebih ramah lingkungan.

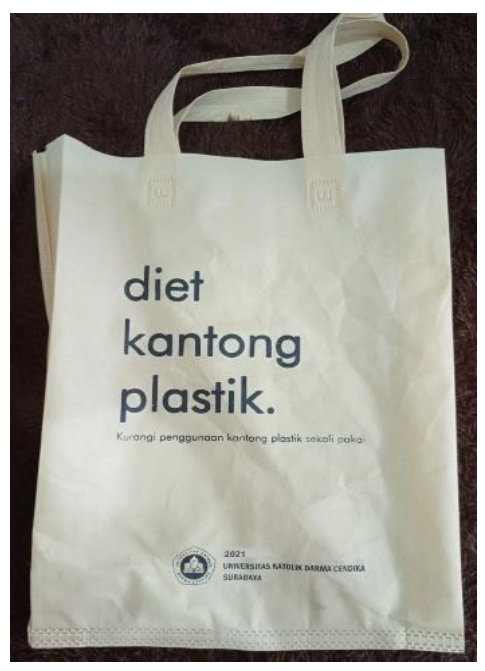

Gambar 1. Tas Reusable Pengganti Tas Platik.

Agar program pengabdian masyarakat ini tetap berkembang dengan baik, maka diharapkan masyarakat Desa Maguwoharjo tetap waspada dengan adanya penyebaran Covid-19 dan tetap waspada dalam menjaga kesehatan diri dengan pola hidup sehat, bersih dan tetap menggunakan masker dan tetap mencuci tangan sebelum ataupun sesudah beraktifitas.

Program Pengabdian Masyarakat ini dilaksanakan guna menjaga kebersihan lingkungan, meningkatkan kesadaran warga dan menumbuhkan kebiasaan untuk mengurangi penggunaan kantong plastik. Diharapkan semangat dan antusiasme warga sekitar untuk mengurangi penggunaan kantong plastik dan beralih ke tas reusable tidak hanya tinggi pada saat mengikuti sosialisasi namun terus dilakukan setiap saat agar tujuan dari dilaksanakannya kegiatan ini benar-benar tercapai. Berikut gambar kegiatan pengabdian oleh tim :

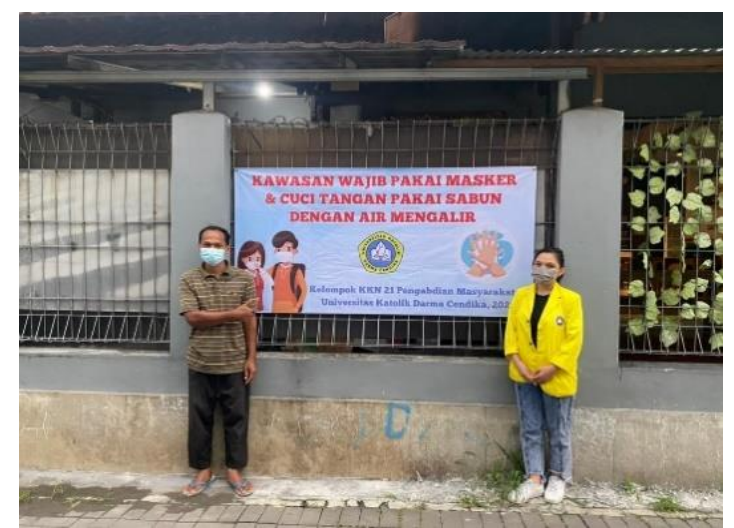

Gambar 2. Pemasangan banner sosialisasi penerapan protokol kesehatan

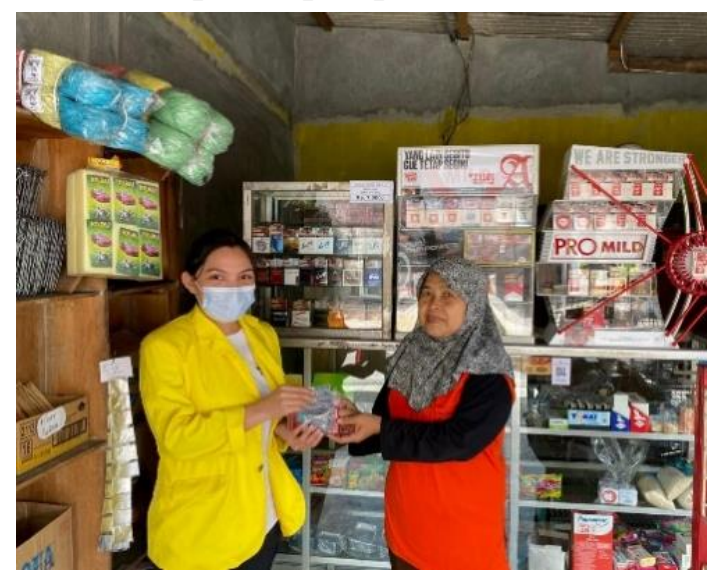

Gambar 3. Pembagian masker kepada warga

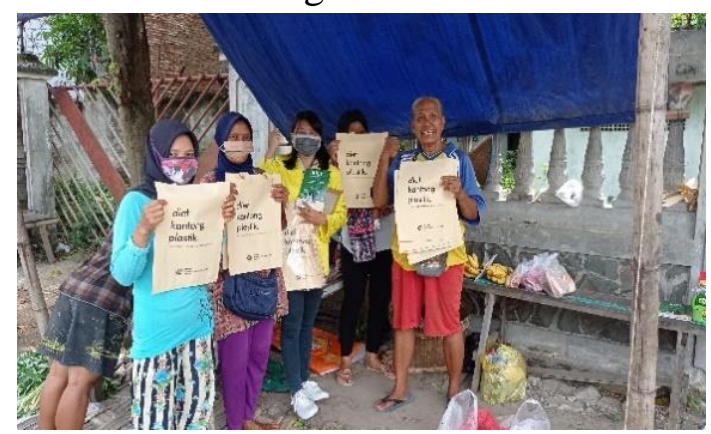

Gambar 4. Sosialisasi dan pembagian tas

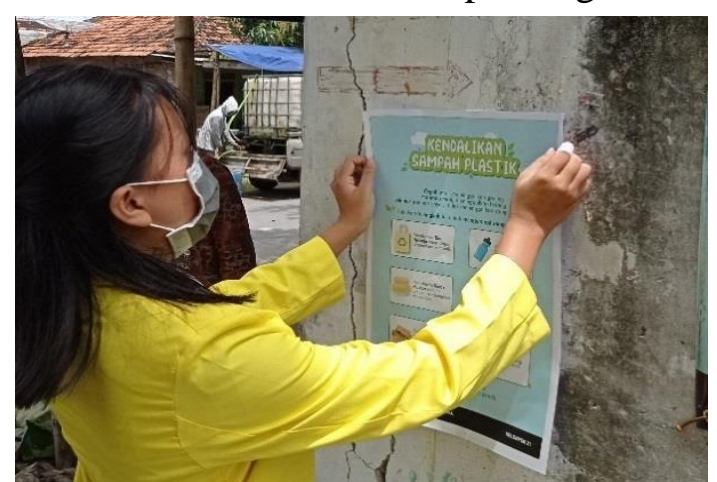

Gambar 5. Sosialisasi melalui poster 


\section{KESIMPULAN DAN SARAN}

\section{Kesimpulan}

Berdasarkan kegiatan Pengabdian Masyarakat yang telah dilakukan oleh Kelompok 21 dapat diambil kesimpulan sebagai berikut:

a.Melalui program kerja pembagian masker, sabun cuci tangan dan pemasangan spanduk diharapkan dapat meningkatkan kesadaran masyarakat untuk tetap menerapkan protokol kesehatan saat beraktivitas selama pandemi masih belum dinyatakan berakhir.

b. Kegiatan ini dilakukan untuk meningkatkan pemahaman masyarakat mengenai upaya preventif terhadap pandemi Covid-19 yaitu dengan cara menaati protokol kesehatan 3M.

c. Dampak positif yang didapatkan setelah dilakukannya sosialisasi tersebut telah dirasakan oleh masyarakat yang rutin menggunakan tas reusable.

d. Banyak ibu-ibu lain yang juga tertarik untuk memulai kebiasaan baru yaitu mengurangi penggunaan kantong plastik dengan beralih ke tas belanja reusable yang lebih ramah lingkungan.

\section{Saran}

Kegiatan Pengabdian Masyarakat yang telah dilaksanakan diharapkan dapat memberikan dampak positif bagi warga setempat. Hasil tersebut dapat digunakan sebagai bahan penyempurnaan pelaksanaan kegiatan pengabdian masyarakat untuk tahun berikutnya, jika menggunakan lokasi ataupun program kerja yang sama, dengan melakukan inovasi dan tetap menggunakan masker serta mencuci tangan sebelum ataupun sesudah beraktifitas. Kebersihan lingkungan semakin terjaga dengan adanya diet kantong plastik yang dilakukan oleh warga yang telah teredukasi. Sehingga sampah plastik dapat berkurang dengan adanya tas belanja dari kain yang dapat digunakan sebagai alternatif pengganti kantong plastik sekali pakai.

\section{DAFTAR PUSTAKA}

http://www.un.org/sustainabledevelopment/ news/communications-material/, diakses pada tanggal 23 September 2021

https://suryawiki.tribunnews.com/, diakses pada tanggal 23 September 2021

https://katadata.co.id/, diakses pada tanggal 23 September 2021

http://repositori.ukdc.ac.id/, diakses pada tanggal 23 September 2021

https://www.academia.edu/50741625/Penin gkatan_Kesejahteraan_Melalui_Penyu luhan_Kewirausahaan_pada_Warga_P KK_di_Dusun_Nanggulan_Kabupaten _Sleman, diakses pada tanggal 23 September 2021 